\title{
The Influence of Religiosity and Social Environment on Volunteerism Practice Among MARA College Students
}

\author{
Abdul Jamir Md Saad, Mohammad Shiham Mahfuz, Nurhaniza Rais Mokhtar \\ \& Siti Suhaila Ihwani
}

To Link this Article: http://dx.doi.org/10.6007/IJARBSS/v11-i4/9743

DOI:10.6007/IJARBSS/v11-i4/9743

Received: 06 February 2021, Revised: 12 March 2021, Accepted: 31 March 2021

Published Online: 17 April 2021

In-Text Citation: (Saad et al., 2021)

To Cite this Article: Saad, A. J. M., Mahfuz, M. S., Mokhtar, N. R., \& Ihwani, S. S. (2021). The Influence of Religiosity and Social Environment on Volunteerism Practice Among MARA College Students. International Journal of Academic Research in Business and Social Sciences, 11(4), 931-940.

Copyright: @ 2021 The Author(s)

Published by Human Resource Management Academic Research Society (www.hrmars.com)

This article is published under the Creative Commons Attribution (CC BY 4.0) license. Anyone may reproduce, distribute, translate and create derivative works of this article (for both commercial and non-commercial purposes), subject to full attribution to the original publication and authors. The full terms of this license may be seen at: http://creativecommons.org/licences/by/4.0/legalcode

Vol. 11, No. 4, 2021, Pg. 931 - 940

Full Terms \& Conditions of access and use can be found at http://hrmars.com/index.php/pages/detail/publication-ethics 


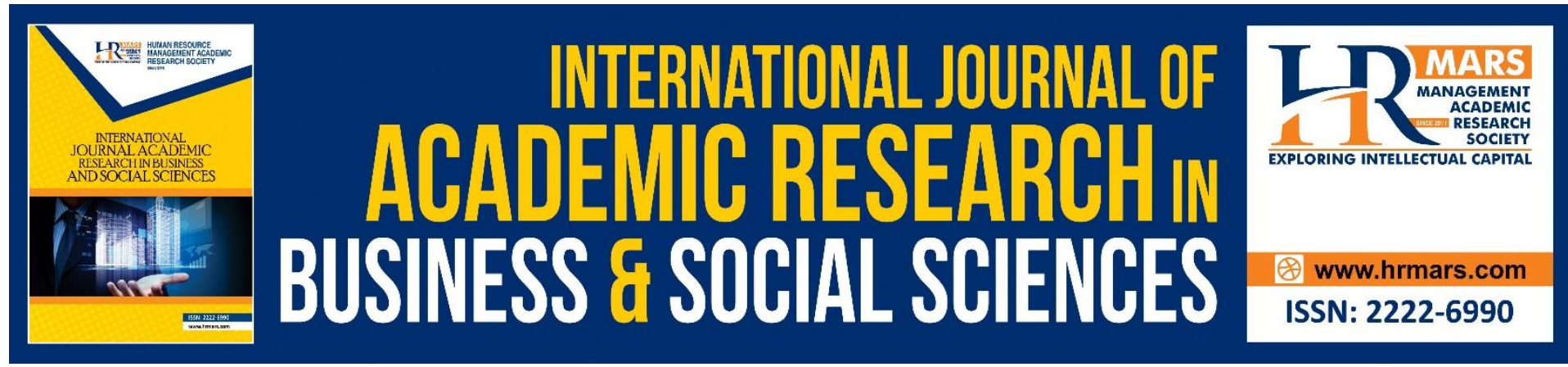

\title{
The Influence of Religiosity and Social Environment on Volunteerism Practice Among MARA College Students
}

\author{
Abdul Jamir Md Saad, Mohammad Shiham Mahfuz, Nurhaniza \\ Rais Mokhtar \& Siti Suhaila Ihwani \\ Academy of Islamic Civilization, Faculty of Social Science and Humanities, Universiti \\ Teknologi Malaysia ( UTM), Malaysia
}

\begin{abstract}
Students are role models that are vital and precious to a country. They are the future leaders that will contribute to the success of their countries. To achieve that goal, students have to be more responsible, attentive and regularly be involved in community activities. Volunteering is also a main trait that is needed and should be integrated into the lives of millennial students that are the apprentices of the country's leaders in the coming age. This group will determine whether a country will be advanced or recede. However, findings from prior researches have shown that the participation of students in volunteering activities have not been up to par, or in other words still moderate. This concept paper discusses the factors that is predicted to influence the participation of students in volunteering activities both at a school and community level. Theories and findings from the past have guided this research paper to suggest that religiosity and social environment are factors that encourage the participation of students in volunteering activities.
\end{abstract}

Keywords: Students, Volunteering, Religiosity, Social Environment, Community Activities

\section{Introduction}

The younger generations or the students these days are the main asset in a country's future development. They are the future leaders that will one day be the leader of the country. They must be prepared with knowledge, skills and a good attitudes or manners so that they will able to succeed and make used of their knowledge, masters various of skills and be a good citizen of the country. They have to be taught and led by the parents, teachers and other people so that they will not be influenced with the bad influences that can destroy their future. The development of the young generation is an important investment for the country and civilization. The participation and contribution of the younger generation towards the volunteerism activities is a crucial issue in the development and also a challenge for the wellbeing of individual and a society (Tamam \& Hashmi, 2015). The younger generation should get themselves active in all the activities involving the social communities. The participation in volunteerism activities is always a good deed.

The spirit to involve in volunteer activities is one of our country and religion demands in national unity framework to face the obstacles of the era. The spirit in volunteering must 
be encourage by culture value, ideology, principle and tradition because it can give a big effect in community and social life (Bahari, 2003). Furthermore, the volunteering activities can also give significant implication in developing a strong country and races. The spirit in volunteering is one of core value that must be have and nurture in our young generation because this generation is the one who will take the responsibility of the advancement and deterioration of the country. Volunteer also helps in building a better community by nurturing a belief among the community by building the value of unity and significant reciprocal for the stability of community (Mihajlovic, 2016). Because of this, the volunteering practice or culture must be nurture and encourage continuously to young generation from the beginning. This spirit must also be nurture by the cooperation of everyone, included the individual, education institution, government, non-government society and also family institution.

Most of the time previous studies show that younger generation involvements in volunteering activities is not only dissatisfying yet it seems to be worsened. This trend is quite worrisome because the aspiration in founding a society that would help each other and also keep the pure traditional values significantly in terms of living in a base of a harmonious community where people would help one another in order to achieve prosperity together. Multiple researchers conducted by Tamam and Hashmi (2015), Warren, Sulaiman and Jaafar (2014) show that younger generation involvements in community services are still not in a satisfactory state (Ibrahim, 2017). The process of fostering the very aspect of volunteering within the students should be taken in a serious manner. This attempt should be developed since their childhood and continued on during their schooling phase up to their University stage. Primary factors that would give a push for them to involve in volunteering activities should be discovered and implemented coherently to increase the number of involvement of youth in volunteering. Henceforth, this discussion would dive further directly within aspects of religious influence and social surroundings towards students' volunteering involvement. These two influences are expected to be major factors of students involvement in volunteering activities and these would also form an interest of volunteering within themselves.

\section{Issues and Concerns}

Recently, one of the issues that's always debated is the decrease of the number of volunteers from the younger generation to be involved actively in volunteer activities. The passion of volunteerism, involvement in community activities voluntarily and the practice of helping each other out are crucial in order to build a good identity for the younger generation whom will be the ones that'll lead our nation in the future. Today's generation seems to be reluctant in doing some social voluntaring activities, for example communal work, neighbourhood security controls, disaster reliefs and etc. The issues of the involvement of students or younger generation in volunteering activities had became more transparent as a result from our new lifestyle that's depended a lot and related to technology. Modern technologies affects the youngsters' lifestyle a great deal. According to Zhang and Lallana (2013) those lifestyle had caused a siginificant decrease in the involvement of the younger generation in volunteer activities compared to the older generation which majority of them still preserves the old lifestyle.

A research conducted by Ibrahim, Amin and Sivabalan (2015) found that the involvement of the young generation in volunteerism activities in this country is at a moderate level. However, the research done by Hussain and Yasin, (2016) stated that the involvement and appreciation of the young generation in volunteering programmes has yet to be 
appreciated. Some individuals thought that volunteering programmes are only the responsibility of those who are silently active under youth organisations and it does not involve the commitment of all parties. These volunteerism activities are seen as a foreign activity that are only done by certain groups at certain times. This understanding must be clarified so that the involvement and appreciation towards the spirit of volunteering will also enhance people's spirit of togetherness (Tahar, 2018). Because of that, volunteerism campaigns and modules need to be empowered ad nurtured, especially among the younger generation especially students. This statement is supported by Musick and Wilson (2014). Their opinion was that all parties must help and work together to expose and encourage the young generation in these volunteering activities. The exposure and encouragement from the community such as family, friends, school, government and Non-profit Organisations (NGO) are really important in opening the minds and enhancing the passion and skills of individuals to expose themselves and cooperate in volunteerism activities.

However, it is undeniable that they're still youth who are willing to participate themselves in activities involving community and volunteering activity. On the other hand, many of them still choose to waste their time by hanging out at the beach, attending a concert , partying, motor racing and involve themselves in crimes. The youth nowadays has been criticised for their less social participation (Warren et al.,2014) Worst situation, when these critics given to made them realise but to make these youth angrier. The latest development shown that these youth tend to show less responsibility in order to help people (Ismail Parnabas, Abdullah \& Hamid, 2014 ), did not participate in social activities plus they tend to stick in their age group.

\section{Participate with Volunteer Activities}

Based on a research conducted to 5223 youth respondents, 27.1 percent of them are interested to participate with volunteer activity and 6.1 percent of them inferred that social activity can cultivate sense of responsibility in an individual. Other than that, to the tune of 22.6 percent of the youth agreed to spend their time and money for volunteering purposes willingly. Results of the study shows as much as 18.2 percent of the youth use their free time for volunteer activity. However, 81.8 percent use their free time for other activities (Institut Penyelidikan Pembangunan Belia Malaysia, 2011). While a research conducted in 2012 concluded 4, 117 of 21, 665 of youth in Malaysia engage in volunteer activity during leisure compared to others who spend it to watch VCD or DVD, take their time to use social web, also having picnic and taking tour. This shows that youth involvement in volunteer activity is still low (Khir, 2016). As a result, the government has launches varieties of volunteer programs to increase youth engagement such as iM4U (Khir, et. al. 2016).

Muhamad and Alauddin, (2013), Awang and Mustafa (2013) believe that the Malaysia's volunteering sector is able to contribute to the country's growth. However, Malaysia is still far behind in many aspects in comparison with other successful countries. Jumat et al (2004) states that it is unfortunate that many students are influenced into thinking that social activities have no benefit whatsoever and only wastes time and money. Thus, few students are active in social activities in the community compared to the actual amount of students in a university. Sahri et. al. (2013) also states the statistic of Public Institution of Higher Education shows that 1.2 million students need to play their role for our nation's growth. One of it is by having volunteering skills and leadership qualities to be useful. This is not merely achieved by attending lectures, but they must be active in social activities to be able to lead by example for the betterment of their country. If we take a glimpse at China, the 
most crucial factor for the younger generation to join volunteering activities is the motivation to attend it (Liao, Chang \& Tsai, 2016). The findings of this study agrees with United Nations (2016) that states that volunteering is to do something without expecting anything in return.

The research carried out by Suanda et. Al., (2016) among Malaysian Institute of Higher Learning (IPTA) students to see how far the spirit of volunteerism Malaysia is as one way to develop volunteerism in education. A total of 3,816 people participated in this study and the findings of the analysis showed that the spirit of volunteerism among Malay students is at the medium level. On the other side, the students have become the focus for volunteering, sports and group events. In order to promote a culture of cooperation and mutual support within the society, the younger generation should be introduced to active involvement in these events while creating a sense of patriotism within them. Furthermore, the disclosure of volunteer engagement for the younger generation is not just about promoting good values but also about creating a quality heir to the country.

According to the study made by Zain et. al. (2014), its stated that voluntary work gives a lot of benefits especially in making change to the welfare and environment of the society. Other than that, volunteering is and activity that does not require any form of payment to the volunteers but they are free to help and spend their time in helping individuals or a community that needs help (Tahar, 2018). Therefore, volunteers are seen as generous, openminded individuals and have a strong sense of identity. According to Zain, Junaidi and Basri (2015), volunteering activities can be developed through environmental education and students are seen to be difficult when forced to do this activity. Therefore, environmental education can help to improve the understanding of students on this activity. Based of Bahari (2016), he stated that if a person is involved in volunteering activities, they are seen as those who are loving towards the environment, highly concerned, as well as having a strong fighting spirit and willingness to sacrifice.

\section{Theoretical Approaches}

This study combines six theory, which are the Planned Behaviour Theory proposed by Aizen (1991) and the Reasoned Action Theory according to Aizen and Fishbein (1980) that becomes the basic principle in this study, followed by supporting theories and models which covers AlGhazali's Value Theory and Character Theory $(1058-1111 / \mathrm{H})$ to elaborate religiousity construct and its influence towards volunteerism in Islam. Meanwhile Human Evolution Ecology Theory by Urie Bronfenbrenner (1986) and Student Aspiration Theory by Hossler and Gallagher (1987) are used to elaborate influence of social environment towards volunteerism. Social influence (socio environment) that is based on Bronfrenbrenner's theory states that social environment exerts a big influence towards an individual's behaviour directly or indirectly. In this study, social influence focuses on the four main aspects, family's influence (parents), peers' influence, the school community's influence and globalization and mass media influence.

According to the Planned Behaviour Theory (1991), accepted behaviour control is the degree of individual control towards a behaviour or action that is going to be done. It is a theoretical model that is often associated with social psychology branch that explains the situation where an individual does not have complete control towards a certain behaviour. This theory also explains the intention to execute a certain behaviour is influenced by attitude towards behaviour, subjective norms and accepted behaviour control. In volunterring activity, the intention factor is the variable of the accepted behaviour control that reflects an individual's perception. As an example, a lot of external sources that influences the intention 
to be involved in volunteering activities like ready to contribute time and riches, share ideas, interested towards activity executed and so on. Meanwhile, internal sources include skills, ability, information, human resource owned, emotion, personality and et cetera. Collision between both, which are the external and internal sources will determine the accepted behaviour control can be continued until it drives a behaviour to be involved in volunteering activities. However, according to this theory even though a volunteer has a strong intention to execute volunteerism program and activity, scarcity of internal and external sources will cause this effort to cease.

Hyde and Knowles (2013) and Penner (2004) reported that volunteerism is a concept that have relation with the theory of planned behaviour of Ajzen. A person will make a judgement within her/his self based on benefits and factors which will motivate and encourage to be involve in charity work. Research about the main intention of a person to be involve in charity work within the youth in Malaysia is still lack, however there is a research (Chacon, Vecina, \& Davila, 2007) prove that intention of a person is the main factor that have strong relation with charity work. In addition, there are three research carried out in Australia prove the theory of planned behaviour of Ajzen can be used to explain the factor of intention of volunteerism; Greenslade and White (2005) explain 75\% variance; Warburton and Terry (2000) 55\% variance and Okun \& Sloane (2002) found 66\% variance involve in charity work. Based on the Theory of Action Reasoning Ajzen and Fishbein (1980), it explains that attitude affect our behaviour in making thorough and grounded decision. This theory includes 2 aspects which are (1) human behaviour is not determined by a general attitude but based on a specific attitude toward something. (2) Human behaviour is influenced not only by attitude, but also by subjective norms. Ajzen and Fishbein (1980) try to seeks a development on understanding attitudes and their relation to human behaviour. They come up with another important theory which is the theory of Reason Action. Kim and Lee (2014) explain that individual behaviour is influenced by the intention to do something based on the influence of attitude toward subjective norms on how to act. This theory further suggests that subjective norms depend on beliefs about one's reach based on one's motivation. According to Ajzen and Fishbein (1980), intention is also an individual's reach of one's behaviour. These two theories serve as the main determinants of student engagement in volunteer practice.

Theory of personal values of Al-Ghazali $(1058-1111 / \mathrm{H})$ is related to emotion, motivation, habluminallah and habluminannas as inner elements that are able to influence human's behavior. Ghazali (2007) gave a picture that Imam Al-Ghazali had emphasized on soul training concept (riyadah al-nafs) and cleaning/purification of soul (tazkiyyah al-nafs) so that it can be applied to humans to shape their attitude and good morals. This assumption theory has been supported by Ibn Miskawaih that individuals should always value true knowledge to improve their behavior and personal values (Al-Ghazali, 2006). According to AlGhazali (1058-1111/H) human's behavior are not only kind or evil, good or bad but it also includes religious morals and Akallah that is able to judge between good and bad. The first assumption on this theory is human's behavior is an inner dynamic drawing and is true to nature in the human's soul that are able to shape their behavior that will lead to goodness. This research also uses personal theory Imam Al-Ghazali. He sees behavior as something that leads to religious aims and humanity. Behavior is closely related between human and their creator, among the humans themselves and between the humans and the creatures around them which is their natural surroundings. In short, Imam Al-Ghazali opinions about behavior is as follows Hussain (2010) and Langgulung, (1999) : i) Behavior has movers (motivation), booster, aim and objective : ii) Motivation is impersonal that comes from human's inner self 
but is stimulated with external and internal stimulations that is related to physical needs and natural tendency like hunger and fear towards Allah: iii) This behavior contains needs and certain feelings and common sense towards that situation: iv) Psychological life is a dynamic behavior which is a continuous interaction between aim or motivation and behavior: v) Behavior is based on different individuals which is affected by descent factor and acquisition or learning process: vi) Behavior has two stages. The first stage is humans are near to all living creatures. The second stage is reaching their ideal dreams and close themselves with deity meaning and angel's behavior. The first level is overpowered by motivation and hurriedness factor, whereas the second level is overpowered by will and mind. This second theory is used for explaining religiosity factor in students' self and the influence towards volunteerism.

Students' social environment factor is also one of the factors that contribute to students' participation in volunteerism. Ecological-evolutionary theory that has been developed by Urie Bronfenbrenner (1986) was based on social environment contract in this research. Based on this theory's concept, a teenager is an individual within a micro (centered) context can be influenced by environmental factor. Teenagers will interact with their environment during their development of self-concept. According to Bronfenbrenner (1986), there are 5 teenagers' environment system which are microsystem, mesosystem, ecosystem, macrosystem and chronosystem. Justification of choosing microsystem and chronosystem in this theory is the researchers want to look at the factor that close to millennial teenagers' personality which is microsystem (family, school and peers) and factor that is believed closely related to nowadays millennial teenager which is chronosystem (media and technology). This is based on considerations from the past research such as Wan et al. (2010), Yahaya, Yahaya and Idris (2012) and Woolfolk (2012).

\section{Conceptual Model}

The conceptual model gives an illustration of the relationship between the several variables used in this study. The conceptual model of this study is based on a combination and gives an adaptation of a number of theories and models to carry out a study regarding the influence of religiosity and social surroundings on the volunteerism of MARA College students. The conceptual framework of this study is based on the Theory of Planned Behaviour by Ajzen (1991) and the Theory of Reasoned Action according to Ajzen and Fishbein (1980) which will be used as the basis of this study. This study will explain further about factors of attitude and the subjective norm factor in the theory related to a more specific dimension which is regarding the religiosity factors and social surroundings in explaining their influence on students' involvement for volunteering activities. Henceforth, this study aims to identify the influence or the religiosity contributions and the social environment regarding the involvement of volunteerism among MARA College students. From an overall view, the conceptual framework of this study can be seen from Figure 1.2 which gives an overview regarding the variables involved in this study. 


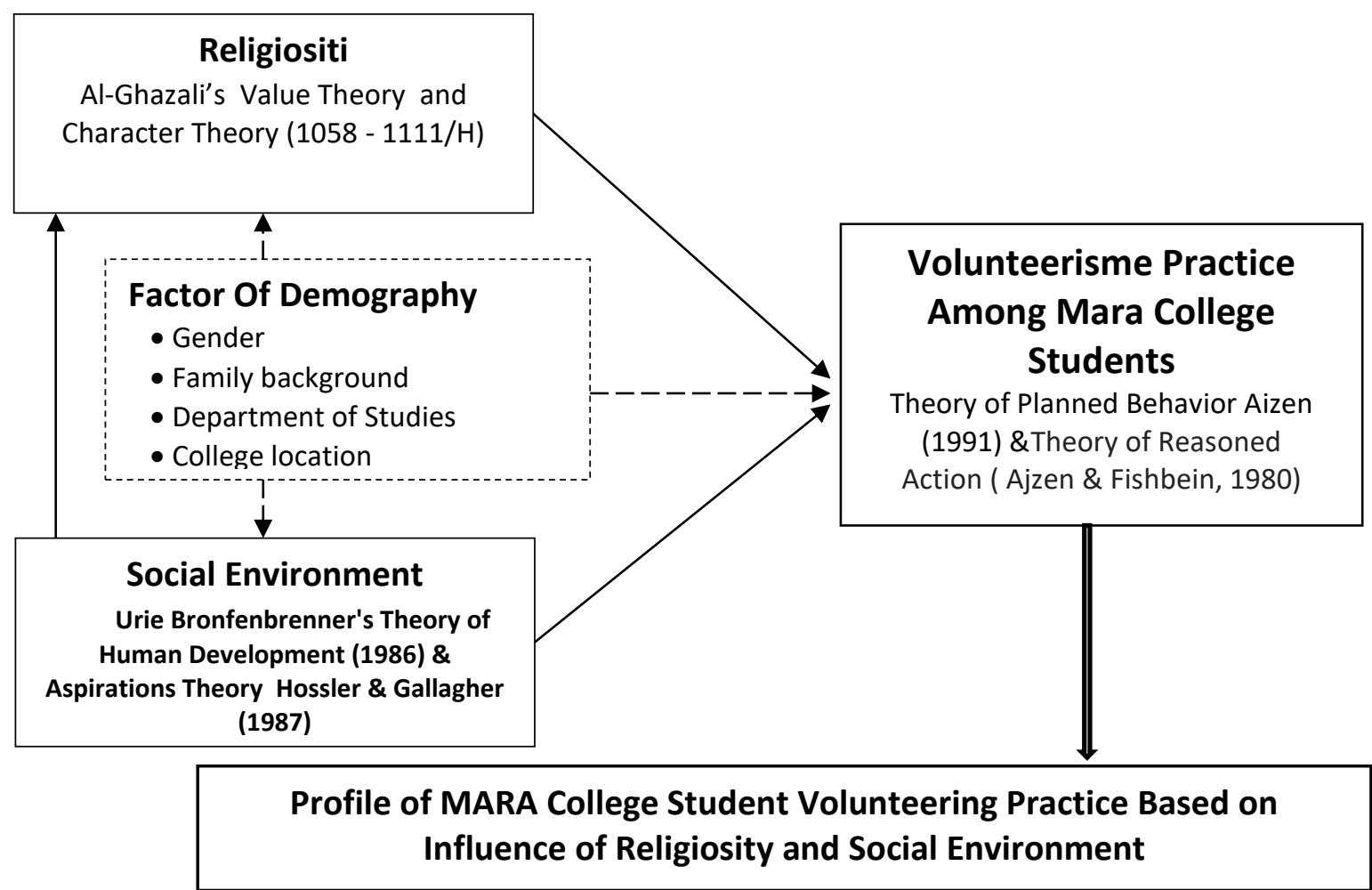

Figure 1. Conceptual framework Adapted and modified from Al-Ghazali's Value Theory and Character Theory $(1058$ - 1111/H) : Urie Bronfenbrenner's Theory of Human Development (1986) \& Aspirations Theory ( Hossler \& Gallagher, 1987) : Theory of Planned Behavior Aizen (1991) \& Theory of Reasoned Action Action ( Ajzen \& Fishbein, 1980)

\section{Conclusion}

Through this, it can be concluded that the behaviour of youths can be predicted via interpersonal communication, virtual communication through media and community-based communication whether that be through the form of neighbourly interactions, welfare clubs, etc. The youth must be guided and given motivation to incorporate effective interpersonal communication with their family, peers, neighbours, and other community members of different ethnicities. Parents and adults in the community must make sure that this is a skill that is possessed by the young generation and is put to practical use in their local communities. In a theoretical context, this skill succeeds in forming a model hypothesis for influencing and creating a social environment for student-volunteering. However, further research must be done to closely observe the correlations of the theoretical model in real practice. Field work such as this will improve the theoretical model and will provide insight into scholarly theories in volunteering-related studies.

\section{References}

Al Ghazali, A. H. (1991). Ayyuhal Walad. Khazanah Al Bayyinah. Versi terjemahan.

Al-Ghazali, A. H. (1994). Ihya' 'Ulumu alDin, Damsyik: Dar al-Khayr.

Al Ghazali, A. H. (1998). Nizam Al-Islam Fil Al-Aqidah Wa Al-Akhlak Wa Al-Tasri'. Damsyik: Dar Al Fikr.

Al-Ghazali, A. H. (1988). Raudah al-Talibin wa' Umdah al-Salikin. Beirut: Dar al-Nahdah alHadithah. 
Ajzen, I. (1991). Theory of Planned behaviour. Organizational Behaviour and Human decision Process, 50, 179-211.

Ajzen, I., \& Fishbein, M. (1980). Understanding attitudes and predicting social behavior. Englewood-Cliffs, NJ: Prentice-Hall

Ali, S. N. (2010). Imam al-Ghazali: Moral and Religious Teachings. Kuala Lumpur: A.S Nordeen. Ariffin, N. (2017). Dorongan Persekitaran Sosial, Kecenderungan Dan Motif Penglibatan Belia Dalam Aktiviti Sukarelawan Berstruktur Serta Sumbangannya Kepada Amalan Nilai Patriotisme. Tesis Dr. Falsafah. Bangi: Universiti Kebangsaan Malaysia.

Bahari, A. (2002) Menghayati kerja sukarela. Qarya Sdn Bhd., Petaling Jaya.

Bahari, A. (2016). Kesukarelawanan. Kangar. Pustaka Qarya

Bronfenbrenner, U. (1986). Recent advances in research on the ecology of human development. In R. K. Silbereisen, K. Eyferth, \& G. Rudinger (Eds.), Development as action in context: Problem behavior and normal youth development . Heidelberg and New York: Springer-Verlag.

Chacon, F., Vecina, M. L., \& Davila, M. C. (2007). The three-stage model of volunteers' duration of service. Social Behavior and Personality: An international Journal, 35 (5), 627-642.

Chong, S. T., (2011). Enhancing youth civic engagement and generalized trust through bonding social capital among friends. Pertanika Journal of Social Sicence \& Humanity 19, 57-64.

Hamzah, S. R. A., Suandi, T., Krauss, S. E., Hamzah, A., \& Tamam, E. (2012). The influences of sociological factors towards hedonistic behavior among Malaysian youth. The Graduate Research in Education Seminar GREduc. Faculty of Educational Studies, Universiti Putra Malaysia. 18 November.

Hussain, T. P. R. S., \& Yasin, L. (2016). Belia dan program kesukarelawan di Malaysia: Satu kajian empirikal. Malaysian Journal of Society and Space (10), 183 - 194.

Hussain, T. P. R. S., \& Yasin, L. (2017). Belia dan program kesukarelawan di Malaysia: Satu kajian empirikal. Geografia-Malaysian Journal of Society and Space, 12(10).

Hussain, T. P. R. S., Nasarah, S. A., \& Othman, Z. (2017). Pembinaan bangsa Malaysia (1): Kajian empirikal tahap patriotisme belia. Geografia-Malaysian Journal of Society and Space, 12(10),

Hyde, M. K., \& Knowles, S. R. (2013). What predicts Australian university students' intentions to volunteer their time for community service? Australian Journal of Psychology, 65(3), 135-145. Doi: 10.1111/ajpy.12014.

Ibrahim, F., Amin, A., \& Sivabalan, T. (2015). Penglibatan dan Motivaasi Kesukarelawanan: Ke Arah Memupuk Semangat Kesukarelawanan Dalam Kalangan Mahasiswa. Journal of Social Sciences and Humanities, 10(1), 84-96.

Institusi Penyelidikan Pembangunan Belia Malaysia. (2017). Accessed from http://www.iyres.gov.my/index.php/ms/

IPPBM. (2011). Indeks Belia Malaysia 2011. Kementerian Belia dan Sukan Malaysia, Putrajaya Ismail, S., Samat, N. A., Parnabas, V., Abdullah, N. M., \& Hamid, N. A. (2014). Youth Volunteerism in Chow kit, Malaysia: Factors of Involvement. In International Conference on Global Trends in Academic Research. Kuala Lumpur (pp. 2-3).

Jumat, S., Maddukelleng, A., Yusuf, A. M., and Omar, M. R., Awang, M. M., and Ahmad, A. (2014). Penglibatan pelajar universiti terhadap aktiviti sosial dalam komuniti pada waktu senggang: Kajian perbandingan di Malaysia dan China. In International Social 
Development Conference 2014 (ISDC 2014), 12 - 13 August 2014, Bayview Hotel Langkawi, Malaysia.

Khir, A. M., Aziz, N. A., \& Nizam, N. M. (2016). Motivasi dan tahap penglibatan belia felda dalam kesukarelawanan di Felda Bukit Rokan, Negeri Sembilan. Journal of Youth Studies 15 (2016), 235-250.

Kim, Y., \& Lee, W. N. (2014). Networking for philanthropy: increasing volunteer behavior via social networking sites. Cyberpsychology, Behavior, and Social Networking, 17(3), 160165.

Langgulung, H. (1999). Pendidikan Islam menghadapi abad ke 21. Jakarta: Pustaka Al-Husna.

Muhamad, T. A., \& Alauddin, A. N. M. (2013). Motif Penglibatan Sukarelawan Sukan Institusi Pengajian Tinggi terhadap Tahap Kepuasan Diri, Jurnal Pendidikan Malaysia (Malaysian Journal of Education), 38(2), 51-59.

Musick, M., \& Wilson, J. (2003). Volunteering and Depression: The Role of Psychological and Social Resources in Different Age Groups. Social Science and Medicine 56(2), 259-269.

Suanda, J., Rezal, H. M., Bahari, A., K. Daud, K. A. K., Hamzah, S. R., Suandi. T, (2012). Semangat Kesukarelawan Dalam Kalangan Mahasiswa Melayu Di IPTA: Satu Tinjauan Ke Arah Pembentukan Pendidikan Kesukarelawan. Seminar Pendidikan Melayu Antarabangsa.

Tamam, E., \& Hashmi, M. (2016). Predicting interethnic bridging social capital in youth ethnicdiversity engagement: The role of interethnic interaction and intercultural sensitivity. International Journal of Adolescence and Youth, 21(1), 1-14.

Warren, A. M., Sulaiman, A., \& Jaafar, N. I. (2014). Facebook: The enabler of online civic engagement for activists. Computers in Human Behavior, 32, 284-289.

Woolfolk, A. (2012). Educational Psychology (12th ed.). New York: Pearson Education.

Yahaya, A., Yahaya, N., \& Idris, F. (2012). Aggressive behavior and the influencing factors at five schools in Johor bahru. Elixir International Journal. Elixir Psychology A, 42, 6530 6536.

Yusoff, W. S., Zulkifli, N. S., Mahmood, A. F., \& Abdul, N. A. (2010). Faktor-faktor yang mempengaruhi penentuan identiti diri remaja melayu. In Seminar Pendidikan Melayu Antarabangsa (pp. 29-31).

Zain, S. M., Junaidi, M. I. M., and Basri, N. E. A. (2015) Sukarelawan alam sekitar: penerimaan dan kefahaman pelajar. Jurnal Personalia Pelajar, 18 (2), 53-59

Zhang, W., \& Lallana, E. C. (2013). Youth, ICTs, and civic engagement in Asia. International Communication Gazette 75, 249-252. 